УДК 332.363

\title{
LAND INVENTORY OF TERRITORIAL COMMUNITIES AS A KEY ELEMENT OF EFFECTIVE LAND RESOURCES MANAGEMENT
}

Patiyuk O.O., postgraduate.

National University of Life and Environmental Sciences of Ukraine o.patiyuk@gmail.com

Fedoruk A.S., technician.

$$
\begin{gathered}
\text { Institute of Land Use of NAAS of Ukraine } \\
\text { alinafedoruk28@gmail.com }
\end{gathered}
$$

Summary. The main resource of $T G$ is lands and the most effective management of this resource provides an opportunity to fill the local budget, develop the community, to carry out error-free and as clear as possible land management, complying with current legislation while taking into account the interests of the community. It also provides transparency in land management, which increases public confidence in local authorities.

If as of today TG is not provided with complete and up-to-date information on the state, qualitative and quantitative indicators of community land resources, then such TG does not meet the challenges of today.

The lack of an updated cartographic basis and land inventory causes: inability to carry out the process of strategic planning of settlements and communities in general, inability to attract investment, low investment attractiveness of the territory, inability to manage land resources in full, inability to meet the needs of the population.

As a result of the study, the distribution of land plots registered in the DZK by ownership, analyzed the data of the DRRP, identified land plots that are not used for their intended purpose, analyzed the urban planning and land management documentation.

Key words: united territorial communities, land resources, land inventory, decentralization. 
Formulation of the problem. Land inventory is carried out in order to establish the location of land management facilities, their boundaries, size, legal status, identification of land that is not used, used irrationally or not for its intended purpose, detection and conservation of degraded agricultural land and contaminated land, establishing quantitative and qualitative characteristics of lands required for the maintenance of the State Land Cadastre, the implementation of state control over the use and protection of lands and the adoption of appropriate decisions on their basis by the executive authorities and local governments [1].

The purpose of the land inventory is to identify the actual available land, land and all supporting documents and bring all the data in line with the actual state of affairs. Land inventory is carried out in accordance with the laws and regulations of Ukraine, in particular the procedure for land inventory is determined by the Resolution of the Cabinet of Ministers of June 5, 2019 №476 "On approval of the land inventory procedure".

Analysis of recent research and publications. The issue of ensuring the inventory of land is covered in the works of such scientists as OS Dorosh, A.G. Martin, M.I. Lakatosh and others.

The purpose of the article there is an analysis of data that can be obtained on the basis of land inventory for effective management of land resources of territorial communities.

Presenting main material. The volume of work performed on land inventory in Ukraine is insufficient, due to both underfunding by the state and lack of interest in their implementation on the ground [6].

In the context of reforming the system of local self-government and the formation of territorial communities, inventory should be considered a necessary element of decentralization policy, as it makes possible the actual transfer of land from state to communal ownership, which significantly increases the economic potential and capacity of united territorial communities.

Inventory, as a form of land accounting, is also an element of the system of protection of land users' rights, because on the basis of information entered into the 
State Land Cadastre of Ukraine after land inventory, land users get the opportunity to determine the amount of losses and damages caused by illegal actions of third parties [2 ] and that is why AG Martin emphasizes that land inventory should have the status of a state management function, and its main tasks should be:

- ensuring the accuracy, completeness and relevance of information on all lands in Ukraine without exception;

- ensuring the validation of cartographic and other information on title documents for each land plot;

- providing information on existing restrictions on land use [3].

E. Lakatosh believes that the inventory "is a way to instantly obtain information about available land for further use in accounting; it is a constant supervision and a set of works aimed at establishing the legal regime and the actual state of land use, their boundaries, sizes, composition of lands for the purpose of rational land use and eliminating the causes of possible violations of land legislation "[4].

The village of Zdorivka, which is part of the Vasylkiv City Territorial Community of the Obukhiv District of the Kyiv Region, was selected for the study.

Effective management of land resources of territorial communities cannot take place without up-to-date data on the state of land use and land composition, so first of all it is necessary to update, or in the absence of order such materials.

The inventory also took into account and analyzed the town-planning and land management documentation available on the territory of the object of study. As a result, it was found that the documentation dates from 1994-2007, which indicates the irrelevance of such data. There was also a lack of cartographic materials on a scale of 1:500-1: 2000.

Based on the analysis, an orthophotoplan (Fig. 1) of 1: 2000 was created on the territory of the object of study using a UAV, which can be used to create a digital plan of land composition, as a basis for making a master plan of the settlement, creating a topographic plan 1: 500-1: 2000 and identification of lands that are used for other purposes. 


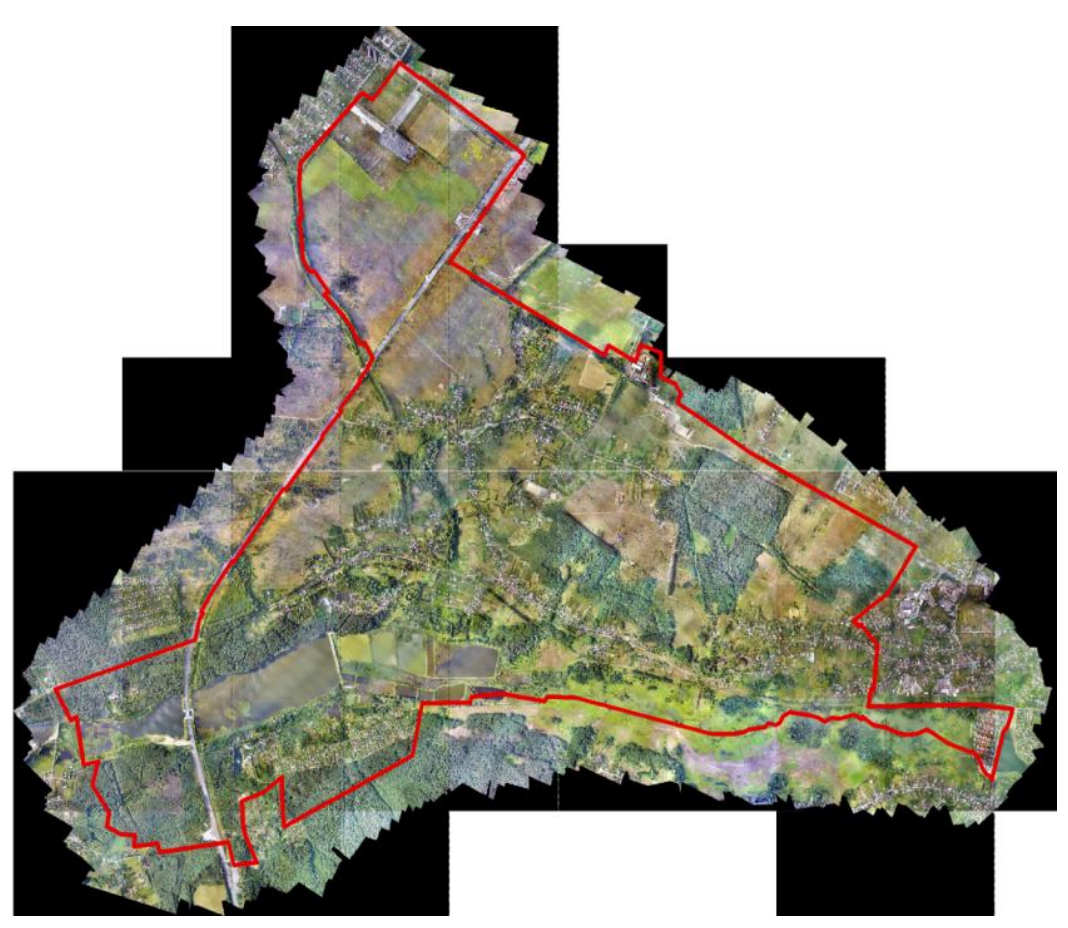

image 1. Orthophotoplan on the territory of Zdorovya village of Vasylkiv city territorial community.

The analysis of information and its distribution in accordance with the spatial and attributive data on the land within the object of study, which are registered in the State Land Cadastre in terms of landowners / land users.

Spatial data included information describing the location and shape of geographical objects and their spatial relationships with other objects, such as the population of the settlement, the list of residents at the specified address. This form of presentation of spatial data consists of various coordinate systems, projections, sets of symbols, methods of simplification and generalization.

Attribute data included information describing the type of use (purpose), area, restrictions on use and more.

Necessary data to describe the analysis of spatial and attributive data on land registered in the State Land Cadastre are information from:

- - Public cadastral map of the State Land Cadastre;

- - State Register of Real Rights to Immovable Property and their Encumbrances (extracts from the DRRP);

- Master plan; 
- - Plan of topographic and geodetic surveying.

To fill and systematize the obtained data, a register of information about the land plot was formed, which is divided into sub-items of spatial and attributive information: cadastral number, purpose, form of ownership, area and presence of border overlay (geometry) in the public cadastral map.

A similar register was created to fill in information on information about the subject of land use and information about the subjects of real rights from the data of the State Register of Real Rights to Immovable Property in relation to land registered in the State Land Cadastre. This register included information on: name of the subject, date of registration, record number, registering authority.

According to the information from these sources, the following was created: a digital plan for providing land plots with data from the State Land Cadastre and the State Register of Real Property Rights.

Necessary data to describe the analysis of the state of land use registered in the State Land Cadastre is information from the data of the Public cadastral map of the State Land Cadastre on:

- Category of lands (purpose);

- Ownership;

- List of restrictions on used and available easements

Table 1 - Legal status of land plots within the village of Zdorivka, Vasylkiv city territorial community

\begin{tabular}{|c|c|c|}
\hline Type of ownership & Number of plots & $\begin{array}{c}\text { Number of plots in } \\
\text { percent, } \%\end{array}$ \\
\hline State & 13 & 0,65 \\
\hline Communal & 69 & 3,45 \\
\hline Private & 1874 & 95,67 \\
\hline Undefined areas & 3 & 0,15 \\
\hline
\end{tabular}

In order to update and comprehensively systematize the initial data on the spatial position and legal status of land plots, the analysis of information from the State Land Cadastre, Public Cadastral Map was assigned. These sources were used 
to obtain information on the legal status and use of land, which includes the purpose, boundaries (geometry) of land and restrictions on use.

he processed information allowed us to create an array of data on the actual legal status of land plots of individuals and legal entities (image 2), as well as to clarify the restrictions on the use and available easements of land plots.

Land plots on which there are restrictions and encumbrances on land use - 79 .

An electronic register of land plots was created, filled with information from the State Land Cadastre and the State Register of Real Property Rights, which allowed to establish the number of plots for which real rights were registered in the amount of 916 of the total number of plots (1959) available in the State Land Cadastre. time of analysis (image 3 ).

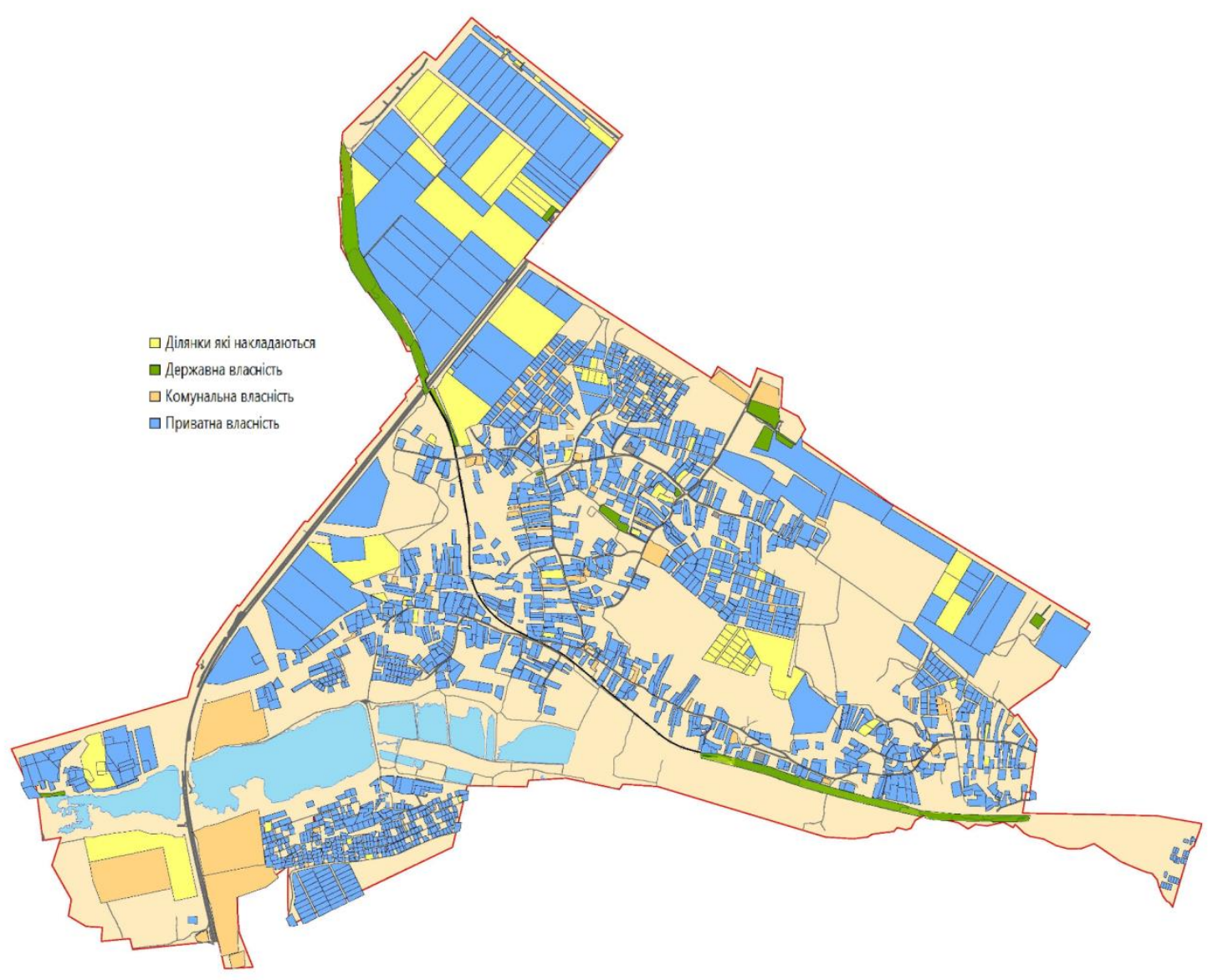

Image .2. Scheme of distribution of land plots by legal status Zdorivka village, Vasylkiv city territorial community. 
According to paragraph 9 of Article $79-1$ of the LCU "On State Land Cadastre" - land may be the object of civil rights only from the moment of its formation (except in cases of sublease, easement on parts of land) and state registration of ownership and in accordance with Art. 125 of the LCU, the right of ownership, in particular, of land arises from the moment of state registration of this right [5].

Currently, land ownership can be registered both through the subjects of state registration of rights and through notaries who are endowed with the powers of state registrars of real estate rights and can carry out state registration of real property rights and their encumbrances without performing a notarial act on such property.

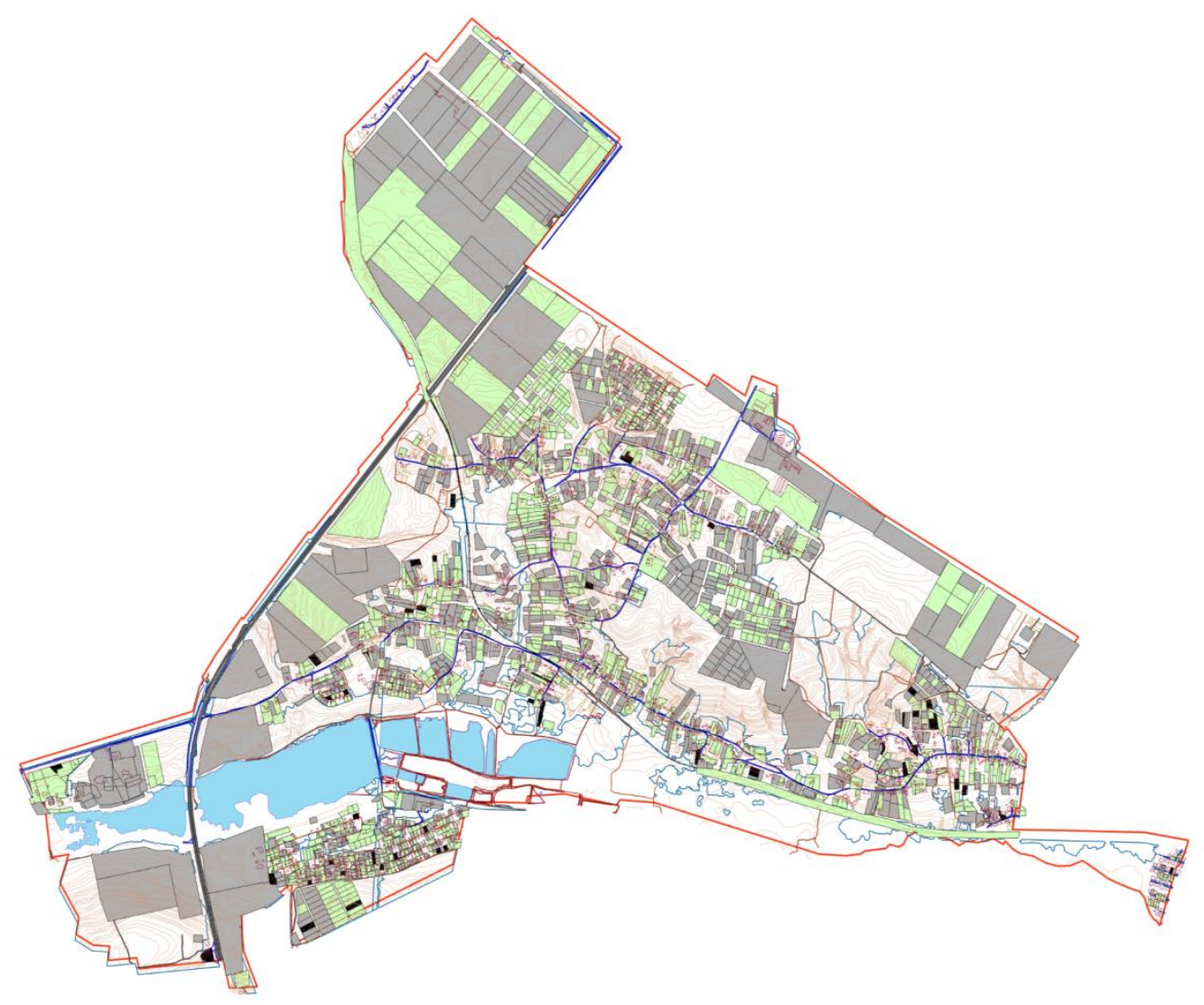

Image 3. Scheme of providing land plots with data from DZK and DRRP Zdorivka village, Vasylkiv city territorial community 
It should also be noted that if within one year from the date of state registration of land in the SCC property right to it will not be registered through the fault of the applicant, the state registration of land is canceled by the state cadastral registrar who carries out such registration.

When canceling the state registration of a land plot, the applicant will have to re-perform all actions on its registration (submit land management documentation for registration, wait for the result, correct remarks if necessary, etc.). And given the frequent changes inherent in land legislation, the rules for developing such documentation, its composition, etc. may change.

Therefore, the applicant (landowner) may incur additional financial costs.

Completeness of receipt of land fee use primarily due to full establishment of local councils, which should be responsible for the established land fee in the respective territories, from full accounting of all land plots actually used (to be provided by the State Geocadastre), from powers of controlling bodies that administer this fee and ensure full and timely payment to the relevant local budgets of land tax and rent for land plots of state and communal property, and, of course, from the proper exchange of information between all these authorities on the subjects and objects of taxation (fee) for land, which as a result can ensure the proper collection of this fee.

On January 1, 2019, the Law of Ukraine of November 23, 2018 № 2628-VIII "On Amendments to the Tax Code of Ukraine and Certain Other Legislative Acts of Ukraine on Improving the Administration and Revision of Rates of Certain Taxes and Fees" entered into force. Subject to paragraph 8.3 of Art. 8 of the TCU, the payment for land, which belongs to the local taxes as part of the property tax, is introduced in the relevant territory by decisions of village, settlement, city councils and councils of territorial communities. Therefore, when taxing land plots with land fees, it is important for taxpayers to correctly apply the relevant decisions of local councils. 
In turn, local councils in making such decisions should not exceed the powers granted to them, which are defined by Article 12 of the TCU. The establishment of local taxes and fees is carried out in the manner prescribed by the PKM.

One of the tasks of the land inventory is - to identify lands that are not used, used irrationally or not for their intended purpose. Therefore, in accordance with the compiled register of land plots registered in the SCC, state-owned land plots were found, which are in permanent use and are actually used for other purposes.:

3221483001:01:0XX:XXXX - Purpose: 01.04 Для ведення підсобного сільського господарства. Використовується під розміщення деревообробної промисловості;

3221483001:01:0XX:XXXX - Purpose: 01.04 For subsidiary agriculture. Used for placement of the woodworking industry;

3221483001:01:0XX:XXXX - Purpose: 01.04 For subsidiary agriculture. Used as an entertainment center, equestrian club;

3221483001:01:0XX:XXXX Purpose: 01.04 For subsidiary agriculture. Used as an entertainment center, equestrian club.

It was also found that a land plot of 0.85 hectares is used by an entertainment center, equestrian club without legal documents, which indicates a lack of local budget

Conclusion. On the example of such land inventory, communities can effectively manage their "land bank", identify lands that are used without title documents, and not for the intended purpose, which brings losses to local budgets. On the basis of the received information on land inventory the full-fledged database on all land plots within the territorial community which will consist of such sections is created.:

- landowners \land users;

- boundaries of land plots;

- purpose;

- ownership;

- area of the land plot; 
- restrictions (encumbrances in use).

Thus, the inventory of land and the creation of a full database of land within the territorial community will serve as a basis for the creation of a geoportal, which will be an important tool for effective management of land resources of the territorial community in real time.

\section{References}

1. Resolution of the Cabinet of Ministers of Ukraine № 476 «Procedure for land inventory». Available at: https://zakon.rada.gov.ua/laws/show/4762019-П.

2. Kulynych P.F. (2007). Vidshkoduvannya vtrat sil's'kohospodars'koho vyrobnytstva yak zasib okhorony sil's'kohospodars'kykh zemel': pravovi pytannya. P.F. Kulynych Chasopys Kyyivs'koho universytetu prava. - № 2. P. 121-126.

3. Martyn A.H. Inventaryzatsiya zemel': yak yiyi zdiysnyuvaty v suchasnykh umovakh. Available at: http://www.zsu.org.ua/index.php?option=com_content $\&$ view=article \&id=2254:2011-05-27-14-48-38\&catid=62:2011-01-12-1457-08\&Itemid $=87$.

4. Lakatosh M.I. (2013) Neobkhidnist' provedennya inventaryzatsiyi zemel' v Ukrayini. Orhanizatsiyno-pravovi peredumovy. M.I. Lakatosh Naukovyy visnyk Uzhhorods'koho universytetu. Seriya «Heohrafiya. Zemleustriy. Pryrodokorystuvannya». - Vyp. 2. - P. 156-161.

5. Land Code of Ukraine. Available at: https://zakon.rada.gov.ua/laws/show/2768-14.

6. Dorosh O. S. Inventaryzatsiya zemel': metodychni pidkhody do yiyi provedennya / O. S. Dorosh // Ahrosvit. - 2015. - № 11. - S. 24-30. Rezhym dostupu: http://nbuv.gov.ua/UJRN/agrosvit_2015_11_5. 


\section{Патиюк А., Федорук А.}

\section{ИНВЕНТАРИЗАЦИЯ ЗЕМЕЛЬ ТЕРРИТОРИАЛЬНЫХ ОБЩИН,}

КАК КЛЮЧЕВОЙ ЭЛЕМЕНТ ЭФФЕКТИВНОГО УПРАВЛЕНИЯ

\section{ЗЕМЕЛЬНЫМИ РЕСУРСАМИ}

Основным ресурсом территориальных общин есть земля и именно эффективное управление этим ресурсом позволяет наполнять местный бюджет, развивать общество, осуществлять безошибочное и максимально четкое распоряжение земельными участками, соблюдая требования действующего законодательства при этом учитывать интересы общества. Также это обеспечивает прозрачность в управлении земельными ресурсами, повымает доверие населения к власти.

Если по состоянию на сегодня территориальная община не обеспечена полной $и$ актуальной информацией о состоянии, качественных $u$ количественных показателей земельных ресурсов общины, то такая территориальная община абсолютно не соответствует вызовам современности.

Отсутствие обновленной картографической основы и инвентаризации земель приводит: невозможность осуществлять процесс стратегического планирования развития населенных пунктов и общества в целом, невозможность привлечения инвестиций, ряд инвестиционная привлекательность территории, невозможность осуществлять управление земельными ресурсами в полной мере, невозможность обеспечения жизненных потребностей населения.

В результате проведенного исследования осуществлено распределение земельных участков, зарегистрированных в ГЗК по формам собственности, проанализированы данные ДРРП, обнаружено земельные участки, используемые не по целевому назначению, проведен анализ градостроительной и землеустроительной документаиии.

Ключевые слова: территориальные общины, земельные ресурсы, инвентаризация земель, деценттрализация. 
Патіюк О., Федорук А.

ІНВЕНТАРИЗАЦІЯ ЗЕМЕЛЬ ТЕРИТОРІЯЛЬНИХ ГРОМАД, ЯК КЛЮЧОВИЙ ЕЛЕМЕНТ ЕФЕКТИВНОГО УПРАВЛІННЯ ЗЕМЕЛЬНИМИ РЕСУРСАМИ

Основним ресурсом територіальних громад є земля і саме ефективне управління цим ресурсом надає можливість наповнювати місцевий бюджет, розвивати громаду, здійснювати безпомилкове та максимально чітке розпорядження земельними ділянками, дотримуючись вимог чинного законодавства при иьому враховувати інтереси громади. Також ие забезпечує прозорість в управлінні земельними ресурсами, що підвищує довіру населення до місиевої влади.

Якщо станом на сьогодні територіальна громада не забезпечена повною та актуальною інформацією щодо стану, якісних та кількісних показників земельних ресурсів громади, то така територіальна громада абсолютно не відповідає викликам сучасності.

Відсутність оновленої картографічної основи та інвентаризації земель зумовлюе: неможливість здійснювати процес стратегічного планування розвитку населених пунктів та громади в иілому, неможливість залучення інвестииій, низка інвестиційна привабливість території, неможливість здійснювати управління земельними ресурсами в повній мірі, неможливість забезпечення життєвих потреб населення.

В результаті проведеного дослідження здійснено розподіл земельних ділянок, які зареєстровані в Державному земельному кадастрі (ДЗК) за формами власності, проаналізовано дані Державного реєстру речових прав (ДРРП), виявлено земельні ділянки, які використовуються не за цільовим призначенням, проведено аналіз містобудівної та землевпорядної документаиії.

Ключові слова: територіальні громади, земельні ресурси, інвентаризація земель, децентралізація. 